\title{
Accessibility to Healthcare and Risk of Polypharmacy on Chronically ill Patients
}

\author{
Suleyman Ersoy ${ }^{1}$ and Velittin Selcuk Engin²
}

\begin{abstract}
Objective: To investigate the rates of polypharmacy (PP) and its relations with accessibility to health services in chronic patients in a primary care setting.

Study Design: A cross-sectional study.

Place and Duration of Study: Melekhatun Family Health Center, Istanbul, Turkey, from January 2014 to January 2017. Methodology: Chronically ill older adults were enrolled in the study. Patients were seen either at home or at health centre. Threshold for PP was five medications daily. Chi-square tests were applied for group comparisons of PP. Continuous variables were examined by Student's t-test. Logistic regressions followed.

Results: Study population ( $n=707)$ consisted of 442 female (62.5\%) and 265 male (37.5\%) subjects. Mean age was 73.6 \pm 7.1 years. Mean number of medicine used per day was $4.7 \pm 3.5$. Polypharmacy rate was $32.8 \%$. Although the number of chronic diseases, that at home patients had, was significantly higher, outpatients had 1.92 times higher risk for PP. Similarly, risk for PP was found 2.57-fold higher in insured patients.

Conclusion: Univariate results of this study suggests that accessibility to health services also increases PP risk, in addition to known risk factors such as female gender, depression and chronic diseases. Same results draw our attention to the risk of inadequate treatment in those who lack health insurance. Longitudinal studies in larger scale are needed for further assessment of these relationships.
\end{abstract}

Key Words: Chronic patient, Polypharmacy, Comprehensive geriatric assessment, Medical insurance, Homebound patient.

\section{INTRODUCTION}

Increased longevity can be regarded among the most outstanding public health achievements of 20th Century. Nevertheless, increased life expectancy means new public health challenges as well as the need for development of health strategies anew. Not only increased chronical diseases, but also increased painful conditions in later life ensue in greater likelihood of polypharmacy (PP) in older adults (OA) compared to other age groups. ${ }^{1}$ In a large scale study from Europe, while PP rate was found $15.8 \%$ in the study sample, this rate was $25.2 \%$ in subjects who were 65 to 74 years old and $27.2 \%$ in the 75 plus population $(p<0.001$ between all age groups). ${ }^{2} \mathrm{PP}$ is associated with increased risk of institutionalisation, mobility impairment, morbidity and mortality. ${ }^{3}$ Although the term PP was defined by $\mathrm{WHO}$, as "the administration of many drugs at the same time or the administration of an excessive number of drugs", this is not the conclusive definition. ${ }^{4}$ Some authors defined PP as consumption of medicines unnecessary or more

1 Department of Family Medicine, Faculty of Medicine, Karabuk University, Alparslan cad, Sirinevler, Karabuk, Turkey

2 Ministry of Health, Melekhatun Family Practice Center, Istanbul, Turkey

Correspondence: Dr. Suleyman Ersoy, Department of Family Medicine, Faculty of Medicine, Karabuk University, Alparslan cad, Sirinevler, Karabuk, Turkey

E-mail: suleymanersoy@gmail.com

Received: August 15, 2018; Accepted: December 11, 2018 than needed, and others assigned threshold values ranging from 2 to 6 for the definition. 1,5,6

Curbing PP requires primary care physicians who are well informed of it. ${ }^{6}$ In Turkey, primary health services were conducted mainly by Family Health Centres (FHCs) which provide continuous access to medicines. Annual number of physician visits per capita is approximately 8.2 in Turkey and more than one-third of these are primary care visits. According to the report issued by Medicines and Medical Devices Institution of Turkey (TITCK) in 2014, 32.071.218 (23.2\%) of the total 138.146.054 prescriptions generated by FHCs were prescribed to patients which were 65 years old or more older. ${ }^{7}$ Primary healthcare is the cornerstone not only in implementation of Rational Use of Drugs (RUD), but also in prevention of undesired outcomes due to excessive or inappropriate consumption of medicines.

In these premises, assessments of PP risk in chronically ill patients who have applied to primary care and its relations with accessibility to health services would be of benefit as a starting point.

The objective of this study was to investigate the PP rates in chronically ill older adults who get healthcare from a FHC, as well as relations of PP with accessibility to medicines (medical insurance) and accessibility to healthcare (outpatient application).

\section{METHODOLOGY}

Consecutive patients who have applied to Melekhatun $\mathrm{FHC}$, Fatih, Istanbul in person or through a relative and 
who were 65 years old or more older between January 2014 and January 2017 were enrolled to this crosssectional study. The inclusion criterion was being chronically ill, regardless of the patient's adherence to treatment. Chronic illness assumed to be present if the subject was diagnosed having at least one of the chronic diseases that requires medical treatment and that has been mentioned in World Health Organization's Global Status Report on Non-communicable Diseases that was issued in 2010.

The sole exclusion criterion was objection to take part in the study that was expressed by patient or legal representatives. All patients were seen either at the FHC or at their homes and their informed consents were obtained. The study was approved by Karabuk University Clinical Research Ethic Committee. All procedures performed in studies involving human participants were in accordance with the ethical standards of the institutional and/or national research committee and with the 1964 Helsinki Declaration and its later amendments or comparable ethical standards.

All patients underwent comprehensive geriatric assessment including detailed history, physical examination, body mass index (BMI), clock drawing (CD) test, three meters walk (TMW) test, instrumental activities of daily living (IADL), mini mental state examination (MMSE), Tinetti's balance and gait scales (TB and TG) and Yesevage's geriatric depression scale (GDS 30 items). Score of $\geq 14$ in GDS scores has been assumed to be the indicative of depressive symptomatology. ${ }^{8}$ Laboratory examinations were performed depending to requirements of each patient. Among these, levels of glycosy- lated hemoglobin ( $\mathrm{HbA} 1 \mathrm{c})$, fasting plasma glucose, lipid subgroups, vitamin B12, folic acid, sero-reactive protein, thyroid functions and complete blood count data were entered to statistical programme when available.

The 'Number of Chronic Diseases' (NCD) counted the number of diagnosed chronic conditions for each subject. Only continuously consumed medicines were taken into consideration while assessing daily drug consumption (DDC). Antibiotics and temporarily consumed analgesics were neglected.

Criteria for the accessibility to healthcare and medicines were assigned as outpatient application and presence of medical insurance, respectively. Being on 5 or more medicines was considered PP in this study. 1,6

Data were evaluated using $17^{\text {th }}$ version of SPSS. While Chi-square test was used to compare PP and control groups in terms of categorical variables, continuous variables were tested by Student's t-test. The level of significance was assumed as $p<0.05$. The variables that were found significantly associated with PP were controlled using logistics regressions. Independent variables that were significantly related to each other (i.e. CD and MMSE) were not added to the model together, in order to avoid collinearity problems.

\section{RESULTS}

Four hundred and forty two (62.5\%) female and 265 $(37.5 \%)$ male patients were enrolled in the study. Mean age was $73.6 \pm 7.1$ years. While 275 out of 707 (38.9\%) were illiterate subjects, who had five years of education or less, constituted the greatest share $(n=420,59.4 \%)$.

Table I: Demographic and clinical features of patients and relation with polypharmacy $\left(\mathrm{DDC}^{*}>5\right)$ : Linear variables.

\begin{tabular}{|c|c|c|c|c|}
\hline Variable & Mean \pm SD & & Mean \pm SD & $\mathrm{p}$ \\
\hline \multirow[t]{2}{*}{ Age } & \multirow[t]{2}{*}{$73.87 \pm 7.3$} & $\mathrm{DDC} \geq 5$ & $74.69 \pm 6.97$ & \multirow[t]{2}{*}{$0.004^{*}$} \\
\hline & & $\mathrm{DDC}<5$ & $73.07 \pm 7.11$ & \\
\hline \multirow[t]{2}{*}{ Body mass index } & \multirow[t]{2}{*}{$29.47 \pm 5.6$} & $D D C \geq 5$ & $30.06 \pm 5.54$ & \multirow[t]{2}{*}{$0.036^{*}$} \\
\hline & & $\mathrm{DDC}<5$ & $29.07 \pm 5.34$ & \\
\hline \multirow[t]{2}{*}{ Waist circumference } & \multirow[t]{2}{*}{$98.5 \pm 12.3$} & $\mathrm{DDC} \geq 5$ & $99.90 \pm 11.74$ & \multirow[t]{2}{*}{0.092} \\
\hline & & $\mathrm{DDC}<5$ & $98.06 \pm 12.17$ & \\
\hline \multirow[t]{2}{*}{ Education year } & \multirow[t]{2}{*}{$3.43 \pm 3.3$} & $\mathrm{DDC} \geq 5$ & $3.43 \pm 3.54$ & \multirow[t]{2}{*}{0.708} \\
\hline & & $\mathrm{DDC}<5$ & $3.32 \pm 3.34$ & \\
\hline \multirow[t]{2}{*}{ Income } & \multirow[t]{2}{*}{$1047 \pm 1532$} & $D D C \geq 5$ & $1247.63 \pm 2277.41$ & \multirow[t]{2}{*}{0.086} \\
\hline & & $\mathrm{DDC}<5$ & $986.59 \pm 1306.61$ & \\
\hline \multirow[t]{2}{*}{ Daily living activity Imp. } & \multirow[t]{2}{*}{$11.1 \pm 4.3$} & $\mathrm{DDC} \geq 5$ & $10.74 \pm 4.34$ & \multirow[t]{2}{*}{0.057} \\
\hline & & $\mathrm{DDC}<5$ & $11.36 \pm 3.93$ & \\
\hline \multirow[t]{2}{*}{ Mini mental score } & \multirow[t]{2}{*}{$25.6 \pm 4.9$} & $D D C \geq 5$ & $26.19 \pm 3.73$ & \multirow[t]{2}{*}{$0.007^{*}$} \\
\hline & & $\mathrm{DDC}<5$ & $25.25 \pm 5.28$ & \\
\hline \multirow[t]{2}{*}{ Tinetti balance score } & \multirow[t]{2}{*}{$14.0 \pm 5.1$} & $\mathrm{DDC} \geq 5$ & $13.57 \pm 3.70$ & \multirow[t]{2}{*}{$0.035^{\star}$} \\
\hline & & $\mathrm{DDC}<5$ & $14.22 \pm 3.21$ & \\
\hline \multirow[t]{2}{*}{ Tinetti gait score } & \multirow[t]{2}{*}{$10.3 \pm 2.9$} & $D D C \geq 5$ & $10.04 \pm 3.11$ & \multirow[t]{2}{*}{$0.017^{*}$} \\
\hline & & $\mathrm{DDC}<5$ & $10.65 \pm 2.55$ & \\
\hline \multirow[t]{2}{*}{ Geriatric depression score } & \multirow[t]{2}{*}{$12.3 \pm 7.5$} & $D D C \geq 5$ & $13.76 \pm 7.66$ & \multirow[t]{2}{*}{$<0.001^{* *}$} \\
\hline & & $\mathrm{DDC}<5$ & $11.55 \pm 7.30$ & \\
\hline \multirow[t]{2}{*}{ Number of chronic diseases } & \multirow[t]{2}{*}{$3.97 \pm 1.96$} & $D D C \geq 5$ & $4.98 \pm 1.83$ & \multirow[t]{2}{*}{$<0.001^{*}$} \\
\hline & & $\mathrm{DDC}<5$ & $3.28 \pm 1.73$ & \\
\hline
\end{tabular}

$\overline{D D C}=$ Daily drug consumption; $\quad{ }^{*} p<0.05 ; \quad{ }^{* *} p<0.001$ 
Table II: Demographic and clinical features of patients and relation with polypharmacy (DDC* $>5)$ : Categorical variables.

\begin{tabular}{|c|c|c|c|c|c|c|}
\hline \multirow{2}{*}{$\begin{array}{l}\text { Variable } \\
\text { Outpatient }\end{array}$} & $\mathrm{N}$ & $\%$ & & $\%$ & Odds ratio (Confidence Interval) & $p$ \\
\hline & 385 & 54.5 & $\begin{array}{l}\mathrm{DDC} \geq 5 \\
\mathrm{DDC}<5\end{array}$ & $\begin{array}{l}39.2 \\
60.8\end{array}$ & $1.92(1.39-2.65)$ & $<0.001^{* \star}$ \\
\hline Female & 442 & 62.5 & $\begin{array}{l}\mathrm{DDC} \geq 5 \\
\mathrm{DDC}<5\end{array}$ & $\begin{array}{l}36.4 \\
63.6\end{array}$ & $1.56(1.12-2.19)$ & $0.008^{*}$ \\
\hline Age over 75 & 275 & 38.9 & $\begin{array}{l}\mathrm{DDC} \geq 5 \\
\mathrm{DDC}<5\end{array}$ & $\begin{array}{l}37.5 \\
62.5\end{array}$ & $1.4(1.02-1.93)$ & $0.036^{*}$ \\
\hline Health insurance & 642 & 90.9 & $\begin{array}{l}\mathrm{DDC} \geq 5 \\
\mathrm{DDC}<5\end{array}$ & $\begin{array}{l}16.9 \\
83.1\end{array}$ & $2.57(1.32-5.03)$ & $0.004^{*}$ \\
\hline Being widowed & 381 & 46.1 & $\begin{array}{l}\mathrm{DDC} \geq 5 \\
\mathrm{DDC}<5\end{array}$ & $\begin{array}{l}36.7 \\
63.3 \\
\end{array}$ & $1.38(1.00-1.88)$ & $0.046^{\star}$ \\
\hline Physical restriction & 103 & 14.5 & $\begin{array}{l}\mathrm{DDC} \geq 5 \\
\mathrm{DDC}<5\end{array}$ & $\begin{array}{l}31.1 \\
68.9\end{array}$ & $1.59(1.03-2.43)$ & $0.034^{*}$ \\
\hline Chronic pain & 372 & 52.6 & $\begin{array}{l}\mathrm{DDC} \geq 5 \\
\mathrm{DDC}<5\end{array}$ & $\begin{array}{l}41.7 \\
58.3\end{array}$ & $2.46(1.77-3.42)$ & $<0.001^{\star \star}$ \\
\hline Adequate water intake & 523 & 73.9 & $\begin{array}{l}\mathrm{DDC} \geq 5 \\
\mathrm{DDC}<5\end{array}$ & $\begin{array}{l}34.9 \\
65.1\end{array}$ & $1.51(1.03-2.19)$ & $0.031^{*}$ \\
\hline Osteoporosis & 137 & 19.3 & $\begin{array}{l}\mathrm{DDC} \geq 5 \\
\mathrm{DDC}<5\end{array}$ & $\begin{array}{l}49.6 \\
50.4\end{array}$ & $2.47(1.68-3.63)$ & $<0.001^{* *}$ \\
\hline Diabetes mellitus & 198 & 28.1 & $\begin{array}{l}\mathrm{DDC} \geq 5 \\
\mathrm{DDC}<5\end{array}$ & $\begin{array}{l}50.3 \\
49.7 \\
\end{array}$ & $2.91(2.07-4.10)$ & $<0.001^{* *}$ \\
\hline Metabolic syndrome & 283 & 39.7 & $\begin{array}{l}\mathrm{DDC} \geq 5 \\
\mathrm{DDC}<5\end{array}$ & $\begin{array}{l}50 \\
50\end{array}$ & $2.44(1.65-3.59)$ & $<0.001^{* *}$ \\
\hline Cerebrovascular disease & 81 & 11.7 & $\begin{array}{l}\mathrm{DDC} \geq 5 \\
\mathrm{DDC}<5\end{array}$ & $\begin{array}{l}45.6 \\
54.4\end{array}$ & $1.88(1.16-3.00)$ & $0.009^{*}$ \\
\hline Hypertension & 172 & 24.4 & $\begin{array}{l}\mathrm{DDC} \geq 5 \\
\mathrm{DDC}<5\end{array}$ & $\begin{array}{l}38.8 \\
61.2 \\
\end{array}$ & $4.11(2.56-6.59)$ & $<0.001^{\star *}$ \\
\hline Cardiac failure & 105 & 15.3 & $\begin{array}{l}\mathrm{DDC} \geq 5 \\
\mathrm{DDC}<5\end{array}$ & $\begin{array}{l}56.2 \\
43.8\end{array}$ & $3.27(2.13-5.00)$ & $<0.001^{* *}$ \\
\hline Atrial fibrillation & 57 & 7.7 & $\begin{array}{l}\mathrm{DDC} \geq 5 \\
\mathrm{DDC}<5\end{array}$ & $\begin{array}{l}53.5 \\
46.5 \\
\end{array}$ & $2.02(1.08-3.78)$ & $0.025^{\star}$ \\
\hline Renal failure & 58 & $8.2 \%$ & $\begin{array}{l}\mathrm{DDC} \geq 5 \\
\mathrm{DDC}<5\end{array}$ & $\begin{array}{l}44.8 \\
55.2 \\
\end{array}$ & $2.79(1.61-4.80)$ & $<0.001^{* *}$ \\
\hline Chronic pulmonary disease & 124 & 17.7 & $\begin{array}{l}\mathrm{DDC} \geq 5 \\
\mathrm{DDC}<5\end{array}$ & $\begin{array}{l}44.4 \\
55.6\end{array}$ & $1.87(1.25-1.77)$ & $0.002^{*}$ \\
\hline Coronary artery disease & 174 & 24.5 & $\begin{array}{l}\mathrm{DDC} \geq 5 \\
\mathrm{DDC}<5\end{array}$ & $\begin{array}{l}50.6 \\
49.4\end{array}$ & $2.90(2.02-4.15)$ & $<0.001^{* *}$ \\
\hline Being demented & 50 & 6.9 & $\begin{array}{l}\mathrm{DDC} \geq 5 \\
\mathrm{DDC}<5\end{array}$ & $\begin{array}{l}52.1 \\
47.9\end{array}$ & $2.41(1.33-4.38)$ & $0.003^{*}$ \\
\hline Gastric disturbances & 304 & 42.9 & $\begin{array}{l}\mathrm{DDC} \geq 5 \\
\mathrm{DDC}<5\end{array}$ & $\begin{array}{l}45 \\
55\end{array}$ & $2.66(1.92-3.68)$ & $<0.001^{* *}$ \\
\hline Anemia & 170 & 24 & $\begin{array}{l}\mathrm{DDC} \geq 5 \\
\mathrm{DDC}<5\end{array}$ & $\begin{array}{l}49.6 \\
50.4 \\
\end{array}$ & $1.73(1.14-2.61)$ & $0.009^{*}$ \\
\hline Interrupted sleep & 226 & 39.4 & $\begin{array}{l}\mathrm{DDC} \geq 5 \\
\mathrm{DDC}<5\end{array}$ & $\begin{array}{l}42.9 \\
57.1 \\
\end{array}$ & $1.48(1.05-2.01)$ & $0.024^{*}$ \\
\hline Onset insomnia & 319 & 45 & $\begin{array}{l}\mathrm{DDC} \geq 5 \\
\mathrm{DDC}<5\end{array}$ & $\begin{array}{l}42.5 \\
57.5\end{array}$ & $1.50(1.07-2.11)$ & $0.018^{*}$ \\
\hline Daytime sleepiness & 239 & 41.7 & $\begin{array}{l}\mathrm{DDC} \geq 5 \\
\mathrm{DDC}<5\end{array}$ & $\begin{array}{l}44.4 \\
55.6\end{array}$ & $1.67(1.18-2.35)$ & $0.003^{*}$ \\
\hline Impaired mobility in TMW & 278 & 39.1 & $\begin{array}{l}\mathrm{DDC} \geq 5 \\
\mathrm{DDC}<5\end{array}$ & $\begin{array}{l}41.2 \\
58.8\end{array}$ & $1.86(1.34-2.56)$ & $<0.001^{* *}$ \\
\hline Incontinence & 213 & 30 & $\begin{array}{l}\mathrm{DDC} \geq 5 \\
\mathrm{DDC}<5\end{array}$ & $\begin{array}{l}45.4 \\
54.6\end{array}$ & $1.64(1.14-2.36)$ & $0.007^{*}$ \\
\hline Major trauma history & 276 & 38.9 & $\begin{array}{l}\mathrm{DDC} \geq 5 \\
\mathrm{DDC}<5\end{array}$ & $\begin{array}{l}42.3 \\
57.7\end{array}$ & $2.03(1.47-2.81)$ & $<0.001^{\star *}$ \\
\hline Dizziness & 347 & 49.1 & $\begin{array}{l}\mathrm{DDC} \geq 5 \\
\mathrm{DDC}<5\end{array}$ & $\begin{array}{l}42.4 \\
57.6 \\
\end{array}$ & $1.53(1.09-2.15)$ & $0.013^{*}$ \\
\hline Fall history & 193 & 27.2 & $\begin{array}{l}\mathrm{DDC} \geq 5 \\
\mathrm{DDC}<5\end{array}$ & $\begin{array}{l}42.7 \\
57.3\end{array}$ & $1.81(1.28-2.55)$ & $0.001^{*}$ \\
\hline Depressive symptomatology & 287 & 42.8 & $\begin{array}{l}\mathrm{DDC} \geq 5 \\
\mathrm{DDC}<5\end{array}$ & $\begin{array}{l}39.0 \\
61.0\end{array}$ & $1.66(1.19-2.29)$ & $0.002^{*}$ \\
\hline
\end{tabular}

$\overline{D D C}=$ Daily drug consumption; $\quad T M W=$ Three meters walk test; $\quad{ }^{*} p<0.05 ; \quad{ }^{*}: p<0.001$ 
Six subjects had graduated from secondary school, 4 from high school and only 2 had university degree $(0.8 \%, 0.6 \%$ and $0.3 \%$, respectively). Mean value for years of education was $3.36 \pm 3.0$.

The study group consisted of $385(54.5 \%)$ outpatients who were seen in FHC; and 322 (45.5\%) homebound patients whose relatives asked for a home visit. Assuming functional limitation as the impairment criterion, the rates of visual and hearing impairment were similar $(n=176,24.9 \%$ and $n=175,24.8 \%$, respectively). At home visits, IADL scores were used to find out whether their reported homebound situations were reflecting the truth. Mean IADL scores of outpatient and homebound ones were $12.90 \pm 2.2$ and $9.03 \pm 4.7$, respectively $(p<0.001)$. At the same time, mobility restriction was detected in $272(38.5 \%)$ patients by TMW and the risk for this was 3.51-fold higher in homebound patients $(p<0.001)$. Self reported physical disability was present in $103(14.6 \%)$ patients and its rate was also significantly increased in homebound patients (4.95 fold, $p<0.001)$.

Sixty-five $(9.2 \%)$ patients lacked medical insurance, while $324(45.8 \%)$ were widowed and $137(19.4)$ were living alone. There were 227 (32.1\%) widows who live with their children, while $264(37.3 \%)$ subjects were living with their spouse and $77(10.9 \%)$ had both spouse and children living with them. Monthly income was assumed absent for those who live on charities $(n=63$, $8.9 \%$ ), while highest income was 30.000 Turkish Liras (TL). Average monthly income was $1085 \pm 1740 \mathrm{TL}$. While smoking history was present in 235 (33.2\%) patients, $61(8.6 \%)$ subjects were still smoking. History of alcohol consumption was documented in 130 (18.4\%) patients, while only $15(2.1 \%)$ were still consuming alcohol.

Mean DDC was $4.7 \pm 3.5$. PP rate turned out to be $32.8 \%$ $(n=232)$. Demographic and clinical characteristics of patients as well as variables that were found significantly related to PP are shown in Tables I and II.

PP risk was 1.4 times higher in those who were above 75 years old $(p=0.036), 1.56$ times higher in women $(p=0.008), 1.38$ times higher in widowed ones $(p=0.046)$, 1.58 times higher in physically handicapped group $(p=0.034), 1.86$ times higher in those whose physical restraint have been detected by TMW $(p<0.001), 1.65$ times higher in those whose depressive symptomatology has been detected by GDS ( $p=0.002$, Table II).

Despite NCD was significantly higher in homebound patients $(p=0.026)$, PP rates were found increased in outpatients $(1.92$ fold, $p<0.0001)$. NCD values were similar in those who were devoid of medical insurance compared to insured ones $(p=0.34)$. However, risk for

Table III: Related variables and their associations with polypharmacy in multiple regressions.

\begin{tabular}{|c|c|c|c|c|c|c|c|}
\hline & \multirow[t]{2}{*}{ B } & \multirow[t]{2}{*}{ Standart Deviation } & \multirow[t]{2}{*}{ Wald } & \multirow[t]{2}{*}{ p. } & \multirow[t]{2}{*}{ Odds ratio } & \multicolumn{2}{|c|}{$95 \%$ Confidence interval } \\
\hline & & & & & & Lower & Upper \\
\hline Outpatient & 0.54 & 0.31 & 3.02 & 0.08 & 1.71 & 0.93 & 3.13 \\
\hline Age & -0.01 & 0.02 & 0.14 & 0.71 & 0.99 & 0.96 & 1.03 \\
\hline Gender & 0.24 & 0.32 & 0.59 & 0.44 & 1.27 & 0.69 & 2.36 \\
\hline Health insurance & 1.07 & 0.67 & 2.55 & 0.11 & 2.91 & 0.78 & 10.82 \\
\hline Body mass index & -0.01 & 0.02 & 0.10 & 0.76 & 0.99 & 0.95 & 1.04 \\
\hline Widowed & 0.39 & 0.25 & 2.44 & 0.12 & 1.48 & 0.91 & 2.40 \\
\hline Diabetes mellitus & 0.92 & 0.25 & 13.41 & $<0.001^{* *}$ & 2.51 & 1.53 & 4.10 \\
\hline Stroke history & 0.43 & 0.38 & 1.28 & 0.26 & 1.54 & 0.73 & 3.24 \\
\hline Hypertension & 0.67 & 0.38 & 3.13 & $0.08^{*}$ & 1.95 & 0.93 & 4.01 \\
\hline Education & 0.04 & 0.28 & 0.03 & 0.87 & 1.05 & 0.61 & 1.79 \\
\hline Gastric disturbance & 0.51 & 0.24 & 4.61 & $0.03^{*}$ & 1.67 & 1.05 & 2.65 \\
\hline Coronary disease & 0.49 & 0.26 & 3.57 & 0.06 & 1.63 & 0.98 & 2.69 \\
\hline GDS & 0.04 & 0.02 & 5.02 & $0.02^{*}$ & 1.04 & 1.00 & 1.08 \\
\hline MMSE & 0.03 & 0.04 & 0.48 & 0.49 & 1.03 & 0.95 & 1.10 \\
\hline Cardiac failure & 0.25 & 0.32 & 0.61 & 0.43 & 1.28 & 0.69 & 2.37 \\
\hline Atrial fibrillation & 0.07 & 0.43 & 0.03 & 0.87 & 1.07 & 0.46 & 2.51 \\
\hline COPD & 0.46 & 0.29 & 2.46 & 0.12 & 1.58 & 0.89 & 2.81 \\
\hline Trauma history & 0.56 & 0.23 & 5.64 & $0.02^{*}$ & 1.75 & 1.10 & 2.77 \\
\hline Osteoporosis & 0.81 & 0.30 & 7.25 & $0.01^{*}$ & 2.26 & 1.25 & 4.07 \\
\hline Pain & 0.13 & 0.27 & 0.22 & 0.64 & 1.14 & 0.67 & 1.94 \\
\hline Renal failure & 1.01 & 0.43 & 5.50 & $0.02^{*}$ & 2.74 & 1.18 & 6.36 \\
\hline Urinary incontinence & -0.07 & 0.27 & 0.07 & 0.79 & 0.93 & 0.54 & 1.59 \\
\hline Falls & -0.10 & 0.30 & 0.12 & 0.73 & 0.90 & 0.50 & 1.63 \\
\hline Anemia & 0.09 & 0.27 & 0.10 & 0.75 & 1.09 & 0.64 & 1.87 \\
\hline TMW restriction & 0.73 & 0.30 & 5.99 & $0.01^{*}$ & 2.08 & 1.16 & 3.74 \\
\hline Difficulty to fall asleep & 0.02 & 0.25 & 0.01 & 0.94 & 1.02 & 0.63 & 1.66 \\
\hline Daytime sleepiness & 0.21 & 0.25 & 0.70 & 0.40 & 1.24 & 0.75 & 2.03 \\
\hline
\end{tabular}

MMSE = Mini Mental Status Examination; $\quad$ GDS = Geriatric depression scale scores; COPD = Chronic obstructive pulmonary disease; TMW = Three meters walk test ${ }^{*}: p<0.05 ; \quad{ }^{* *}: p<0.001$ 
PP also was increased in insured patients $(2.57$ fold, $p=0.004$ ).

The variables that were found significantly associated with higher DDC in univariate tests were added in logistic regressions along with possible confounders. Ultimately, these factors were significant in regressions.

Diabetes mellitus $(p<0.001)$, gastric disturbances $(p=0.032)$, higher GDS scores $(p=0.025)$, major trauma history $(p=0.018)$, osteoporosis $(p=0.007)$, restricted mobility in TMW $(p=0.014)$, renal insufficiency $(p=0.019$, Table III).

\section{DISCUSSION}

The rate of PP was lower in our study compared to most of the literature. Studies that were conducted with community dwelling older adults in, Iceland, USA, Australia and Italy have reported PP rates as high as, $41 \%, 43.4 \%, 35.8 \%$ and $46.8 \%$, respectively. ${ }^{9-12}$ In institutionalised older adults, the rates are even higher as is the case with SHELTER study, which reported the rate as $49.7 \%$ in nursing homes of eight European countries. ${ }^{13}$ However, in a study from Germany, which also conducted in primary care setting, PP rate was found to be $26.7 \%$ among older patients, and DDC was found 5.1 .6 These findings are very close to the present results.

In a multi-centre study that was conducted in 12 cities from Turkey, average DDC was found 2.69 and average PP rate was $17 \%$. This study also reported marked variability of $\mathrm{PP}$ according to the region. ${ }^{14}$ The rates of PP are not as low as this in metropolitan cities of Turkey. A geriatric clinic of the Hacettepe Medical School in Ankara has reported the rate as high as $41.2 \% .15$

In this study, demographic characteristics as female sex, being educated, presence of medical insurance, being widowed, as well as chronical diseases such as diabetes mellitus (DM), hypertension and heart failure were found associated with PP along with a variety of scales in univariate analyses (Table I). While the rate of PP was $32.8 \%$ in average, it was $36.4 \%$ in women subjects. Previous studies that were conducted in Istanbul have also found higher rates of PP in older women. As an example, a study reported 2.21 times higher risk for PP in older female patients who applied to a geriatric clinic of a university hospital, compared to male counterparts. ${ }^{15}$ In another university clinic, while reported PP rate was $40 \%$ in older adults, this rate was $36 \%$ in men and $42 \%$ in women. ${ }^{16}$

Logistic regressions revealed seven independent predictors of PP: DM $(p<0.001)$, gastric disturbances $(p=0.032)$, higher GDS scores $(p=0.025)$, history of major trauma $(p=0.018)$, osteoporosis $(p=0.007)$, restricted mobility in TMW $(p=0.014)$, renal insufficiency $(p=0.019)$. These results are compatible with the literature. ${ }^{10,12}$
Chronic diseases are well known risk factors for increasing the burden of medications and PP. There are studies showing this for DM, ${ }^{17}$ depression, 18,19 renal insufficiency, ${ }^{20}$ osteoporosis ${ }^{21}$ and gastric disturbances, ${ }^{22}$ in older adults.

In terms of the aim of the study, the most relevant findings are increased PP risk in both outpatients and insured ones. Disregarding the social influences, one may expect this bias to be in favour of those who had worse health conditions. Indeed, NCD was significantly higher in homebound patients, as is the case for restriction in TMW, which turned out to be an independent predictor of PP in regressions.

Uninsured patients had higher NCD too, but not to the level of statistical significance. The paradoxical risk increases in insured subjects and outpatients (2.57 and 1.92 fold, respectively) suggest an influence of accessibility to health care on PP.

The health transformation project which commenced in 2003 has improved the medical insurance system in Turkey. It was followed by Family Practice (FP) system that has been implemented nationwide in 2010. These developments not only improved the health parameters, but also cleared the obstacles to health services to a great extent. ${ }^{23}$ Although these are favourable outcomes in the sense of citizens, they may also bring about an increased risk of inappropriate or excessive medicine consumption.

It may be regarded as an important data in many senses which should be taken into consideration in health planning that PP was found linked to accessibility to health services in chronic patients over 65 years old. This is partly because the same information draws our attention to under treatment, which is a health related problem as significant as PP. 24 It was reported that $15 \%$ of the patients had failed to adhere to their treatment due to lack of medical insurance in 2004. After extension of subsidised medicines list by Medicare, this rate has declined to $11.5 \%$ in 2006. Also strikingly, risk for undertreatment was reported to be increased in those who were physically handicapped, who reported their health condition unfavorable, and who had more chronic diseases. ${ }^{25}$ Findings in this study confirm this issue.

Inequality in health services may ensue in inappropriate medicine use on both sides. This fact further extends the targets for policies of RUD, as underserved patients are at stake as well. As this is a single centre crosssectional study, it would not be appropriate to extrapolate these results to general population. Although these are univariate findings, they draw our attention to inappropriate as well as insufficient treatment issues in older patients whose chronic conditions have played an essential role in their accessibility to health services. These results may provide precious information for the multi-centre and prospective studies aiming proper 
definition of the challenges to RUD, and ultimately curbing rates of PP as well as under treatment.

\section{CONCLUSION}

Restricted mobility in TMW was independently associated with PP in regressions, but outpatients rather than homebound patients had significantly increased risk of PP. On the other hand, in the homebound patients, who used fewer medicines, NCD was significantly increased. Insured patients had significantly higher risk of PP.

\section{REFERENCES}

1. Slabaugh SL, Maio V, Templin M, Abouzaid S. Prevalence and risk of polypharmacy among the elderly in an outpatient setting: A retrospective cohort study in the Emilia-Romagna region, Italy. Drugs Aging 2010; 27:1019-28.

2. Niclós G, Olivar T, Rodilla V. A cross-sectional evaluation of the prevalence and detection of predictors of polypharmacy amongst adult in Spain. Int J Pharm Pract 2018; 26:242-9.

3. Trygstad TK, Christensen D, Garmise J, Sullivan R, Wegner S. Pharmacist response to alerts generated from Medicaid pharmacy claims in a long-term care setting: results from the North Carolina polypharmacy initiative. J Manag Care Pharm 2005; 11:575-83.

4. WHO Centre for Health Development. A glossary of terms for community healthcare and services for older persons. World Health Organization, editor. 2004. Geneva, Switzerland. Ageing and Health Technical Report.

5. Walckiers D, Van der Heyden J, Tafforeau J. Factors associated with excessive polypharmacy in older people. Arch Public Health 2015; 73:50.

6. Junius-Walker U, Theile G, Hummers-Pradier E. Prevalence and predictors of polypharmacy among older primary care patients in Germany. Fam Pract 2007; 24:14-9.

7. Benli AR. Rational drug use in geriartric population in primary health care services. Ankara Med J 2015; 15:258-9.

8. Yesavage JA, Brink TL, Rose TL, Lum O, Huang V, Adey M, et al. Development and validation of a geriatric depression screening scale: A preliminary report. J Psychiatr Res 19821983; 17:37-49.

9. Sigurdardottir AK, Arnadottir SA, Gunnarsdottir ED. Medication use among community-dwelling older Icelanders. Populationbased study in urban and rural areas. Laeknabladid 2011; 97:675-80.

10. Heuberger RA, Caudell K. Polypharmacy and nutritional status in older adults. Drugs Aging 2011; 28:315-23.

11. Beer C, Hyde Z, Almeida OP, Norman P, Hankey GJ, Yeap BB, et al. Quality use of medicines and health outcomes among a cohort of community dwelling older men. Br J Clin Pharmacol 2011; 71:592-9.

12. Nobili A, Franchi C, Pasina L, Tettamanti M, Baviera M, Monesi L, et al. Drug utilization and polypharmacy in an Italian elderly population: the EPIFARM-elderly project. Pharmacoepidemiol Drug Saf 2011; 20:488-96.

13. Onder G, Liperoti R, Fialova D, Topinkova E, Tosato M, Danese P, et al. Polypharmacy in nursing home in Europe: Results from the SHELTER study. J Gerontol A Biol Sci Med Sci 2012; 67:698-704.

14. Gokce Kutsal Y, Barak A, Atalay A, Baydar T, Kucukoglu S, Tuncer $\mathrm{T}$, et al. Polypharmacy in the elderly: A multicenter study. J Am Med Dir Assoc 2009; 10:486-90.

15. Kara Ö, Arik G, Kizilarslanoglu MC, Kilic MK, Varan HD, Sümer F, et al. Potentially inappropriate prescribing according to the STOPP/START criteria for older adults. Aging Clin Exp Res 2016; 28:761-8.

16. Yuruyen M, Yavuzer H, Demirdag F, Kara Z, Cengiz M, Yavuzer $\mathrm{S}$, et al. Is depression a predictive factor for polypharmacy in elderly? Klinik Psikofarmakoloji BülteniBulletin of Clinical Psychopharmacology 2016; 26:374-81.

17. Formiga F, Vidal X, Agustí A, Chivite D, Rosón B, Barbé J, et al. Inappropriate prescribing in elderly people with diabetes admitted to hospital. Diabet Med 2016; 33:655-62.

18. Ersoy S, Engin VS. Risk factors for polypharmacy in older adults in a primary care setting: A cross-sectional study. Clin Interv Aging 2018; 15:2003-11.

19. Engin S, Ozturk M, Engin N, Kulaksizoglu IB. Dark side of the town: Depressive symptoms in disadvantaged senior citizens. J Nutr Health Aging 2010; 14:483-7.

20. Jones SA, Bhandari S. The prevalence of potentially inappropriate medication prescribing in elderly patients with chronic kidney disease. Postgrad Med J 2013; 89:247-50.

21. Gosch M, Jeske M, Kammerlander C, Roth T. Osteoporosis and polypharmacy. Z Gerontol Geriatr 2012; 45:450-4.

22. Trumic E, Pranjic N, Begic L, Becic F. Prevalence of polypharmacy and drug interaction among hospitalized patients: opportunities and responsabilities in pharmaceutical care. Mater Sociomed 2012; 24:68-72.

23. Atun R. Transforming Turkey's health system-lessons for universal coverage. N Engl J Med 2015; 373:1285-9.

24. Bahat G, Akpinar TS, Tufan F, Akin S, Tufan A, Erten N, et al. Rational drug use in the elderly. $J$ Gerontol Geriatric Res 2011; 1:1-8.

25. Soumerai SB, Pierre-Jacques M, Zhang F, Ross-Degnan D, Adams AS, Gurwitz J, et al. Cost-related medication nonadherence among elderly and disabled medicare beneficiaries: A national survey 1 year before the medicare drug benefit. Arch Intern Med 2006; 166:1829-35. 